\title{
Event-duration semantics in online sentence processing
}

\author{
Semântica da duração de eventos no processamento online de sentenças \\ Thiago Oliveira da Motta Sampaio \\ Universidade Estadual de Campinas, Campinas, SP, Brasil \\ Aniela Improta França \\ Universidade Federal do Rio de Janeiro, Rio de Janeiro, RJ, Brasil
}

$\diamond$

\begin{abstract}
Several experiments in Psycholinguistics found evidences of Iterative Coercion, an effect related to the reanalysis of punctual events used in durative contexts triggering an iterative meaning. We argue that this effect is not related to aspectual features, and that event-duration semantics is accessed during Sentence Processing. We ran a self-paced reading experiment in Brazilian Portuguese whose sentences contain events with an average duration of a few minutes. These sentences were inserted in durative contexts that became the experiment's conditions following a Latin Square design: control condition (minutes), subtractive (seconds), iterative (hours) and habitual (days). Higher RTs were measured at the critical segments of all experimental conditions, except for the habitual context. The results corroborated our hypothesis while defying the psychological reality of habitual coercion. To better observe the habitual coercion condition, we now present a reanalysis of Sampaio et al. (2014) data. The present analysis confirms the results of our tests.
\end{abstract}

Keywords: Sentence processing; Semantics of time; Event duration; Time perception; Aspectual coercion

Resumo: Diversos experimentos psicolinguísticos encontraram evidências da Coerção Iterativa, um efeito relacionado à reanálise de eventos pontuais usados em contextos durativos, que resultam numa leitura iterativa. Nesse trabalho argumentamos que esse efeito não é relacionado a propriedades aspectuais e que a semântica da duração dos eventos é acessada online. Aplicamos um experimento de leitura auto-monitorada em Português Brasileiro, cujas sentenças contém eventos com duração média de alguns minutos. Estas sentenças foram inseridas em quatro condições durativas, seguindo uma distribuição fatorial (quadrado latino): condição controle (minutos), subtrativa (segundos), iterativa (horas) e habitual (dias). Nossos resultados indicam maiores RTs nos segmentos críticos das condições experimentais, exceto em relação a condição habitual. Esses resultados confirmam nossa hipótese, porém, põem em cheque a realidade psicológica da coerção habitual. Assim, para melhor observar os efeitos dessa condição, procedemos uma reanálise dos dados de Sampaio et al. (2014), que finalmente veio confirmar o resultado de nosso teste.

Palavras-chave: Processamento de sentenças; Semântica do tempo; Duração de eventos; Percepção do tempo; Coerção aspectual 


\section{Introduction}

Much before the glamorous Hollywood release of Dennis Villeneuve's 'The Arrival' (2017) tried to establish a link between language and time, several works have been produced by linguists and psychologists aiming at identifying time properties in the cognitive domain of language (REICHEMBACH, 1947; ALFORD 1981; HORNSTEIN, 1993; MANI et al. 2005; COLL-FLORIT; GENNARI, 2011; SAMPAIO, 2015; 2016; FABER; GENNARI, 2015; GAUTHIER; VAN WASSENHOVE, 2016, 2017; BYLUND; ATHANASOPOULOS, 2017). Language forms complex objects that relate form and meaning. It also seems to be inextricably connected to time since speech becomes acoustic waves that are linearly or serially absorbed by the receptor. This paper aims at testing the hypothesis that the semantics of time affects online sentence processing, based on studies of the so-called aspectual coercion effect (SAMPAIO; FRANÇA; MAIA, 2014; SAMPAIO, 2015). It is a covert mechanism of linguistic system that allows us to understand the difference between two durative sentences having the same structure but different verbal aspects. Consider the following examples.

(1) a. The child cried for two minutes

b. The child sneezed for two minutes

(1a) has a durative event composed of a durative verb (to cry) in a durative context (for two minutes). In this example, both verb and context share the same aspectual properties of being a single durative crying event. On the other hand, (1b) is composed by a punctual verb (to sneeze) and a durative context. The result is an aspectual mismatch that triggers a multiple event reading in which 'sneezes' can last for two minutes. This effect is Aspectual Coercion. In this trajectory, Pustejovsky (1995), Jackendoff (1997), De Swart (1998) proposed the coercion hypothesis. De Swart (1998) define Aspectual Coercion in the following terms:

Typically, coercion is triggered if there is a conflict between the aspectual character of the eventuality description and the aspectual constraints of some other element in the context. The felicity of an aspectual reinterpretation is strongly dependent on linguistic context and knowledge of the world (DE SWART, 1998, p. 360).

Dölling (2014), however, defines coercion in different terms. He proposes his own Event Classification in which verbs have no fixed classes and pragmatic can change the aspectual properties of an event depending of its context.
Sampaio et al. (2014) and Sampaio (2015; 2016) follow a different logic for the explanation of coercion effects, linking sentence processing and time perception studies in cognitive psychology. When one reads a sentence, the average subjective duration of this event is activated. If the sentence has an overt duration (eg. for some minutes) and sentence duration has a mismatch with event duration, we can observe the coercion effect on sentence processing experiments.

In this paper, we present a self-paced reading test to investigate the psychological reality of Sampaio and colleague's proposal. Our first experiment, described in the section 3 , presents evidences that aspectual coercion can be observed using durative events in different durative contexts. In the section 4 , we present a reanalysis of Sampaio, França \& Maia (2014) in which we had reported different and inconsistent effects.

\section{Aspectual Coercion}

In the last century, Descriptive Linguistics identified some properties related to the temporal frame of events, namely telicity, progression and duration. For instance, encoded in the temporal frame of events might be the existence of an inherent endpoint (telicity; 'eat an apple', the apple measures the event), its progression (gerunds: 'eating an apple') or its duration (punctual or durative: 'to sneeze' $\times$ 'to eat'). These properties are the ingredients of Aspect and they are present both in the verb meaning (the meaning of sing in 'John sang a song') and in the adjoined temporal context ('for three minutes'). Aspectual mismatches between the verb and its temporal context lead to Aspectual Coercion (PUSTEJOVSKY，1995; JACKENDOFF，1997; DE SWART, 1998).

The most likely hypothesis for the existence of aspectual coercion is a clash between punctual and durative events. Brennan \& Pylkkänen (2008) appropriately renamed it as Iterative Coercion Hypothesis. Imagine a punctual event such as 'John sneezed', combined to a durative context such as 'for three minutes'. As a punctual event, one single sneeze cannot last for three minutes. In this case, we are forced to reanalyze the verb as referring to an iterative event, now "John sneezed [several times] for three minutes". In this view, durative events in durative contexts ('John worked all the day long') and punctual events in punctual contexts ('John sneezed right now') would not present any coercion effects because they share aspectual properties with their temporal predicate.

The Iterative Coercion Hypothesis (ICH) has been supported by experimental data in audio-visual cross modal experiments (PIÑANGO et al. 1999), self-paced 
reading protocols (TODOROVA et al. 2000a, $\mathrm{b}^{1}$; CHEN 2013), eye tracking (PICKERING et al. 2008; TWONSEND, 2012) and electrophysiological measures such as EEG (PACZYNSKI et al. 2014; YANO 2016; BŁASZCZAK; KLIMEK-JANKOWSKA, to appear) and MEG (BRENNAN; PYLKKÄNEN, 2008).

However, the clash between punctual and durative events of ICH has been challenged in the last few years. For instance, Dölling (2014) developed what we call here Event-Classification-Driven hypothesis ${ }^{2}$. According to this author's view, verbs have no fixed event classification and bounce back and forth among his 13 event classes and subclasses (DÖLLING, 2014; Figure 3). Among them, 9 changes of classes are described by the author ${ }^{3}$. Each one is considered a different type of aspectual coercion. For example, a moment, such as the one John slept, can be turned into an event by stretching coercion (2a), the state of "be clever" can be used in a specific occurrence by agentive coercion (2b), and an event can be clearly interpreted as an incomplete process as the sentence context is not enough for event completion (2c).
(2) a. John slept at 3 o'clock $=>$ John slept for 3 hours (stretching coercion)

b. John is clever $=>$ John is being clever (agentive coercion)

c. The musician played a sonata for 2 minutes (subtractive coercion)

Sampaio's proposal (SAMPAIO et al., 2014; SAMPAIO, 2015; 2016) looks at coercion as a kind of time perception phenomenon 4 and will be called "TimePerception-Driven Hypothesis". Once punctual events are coerced into repetition in durative contexts, the same should happen to durative events when they are inserted in shorter and in larger durative contexts, following the Figure 1 and the example (3) bellow. Remark that, following the logics of pragmatic studies, subtractive and habitual coercion were also proposed by Dölling (2014) so, the main difference here are (i) the nature of each proposal (coercion is a pragmatic or a semantic effect?) and (ii) the number of coercion effects. The Time Perception-Driven hypothesis can be summed up in the Figure 1.

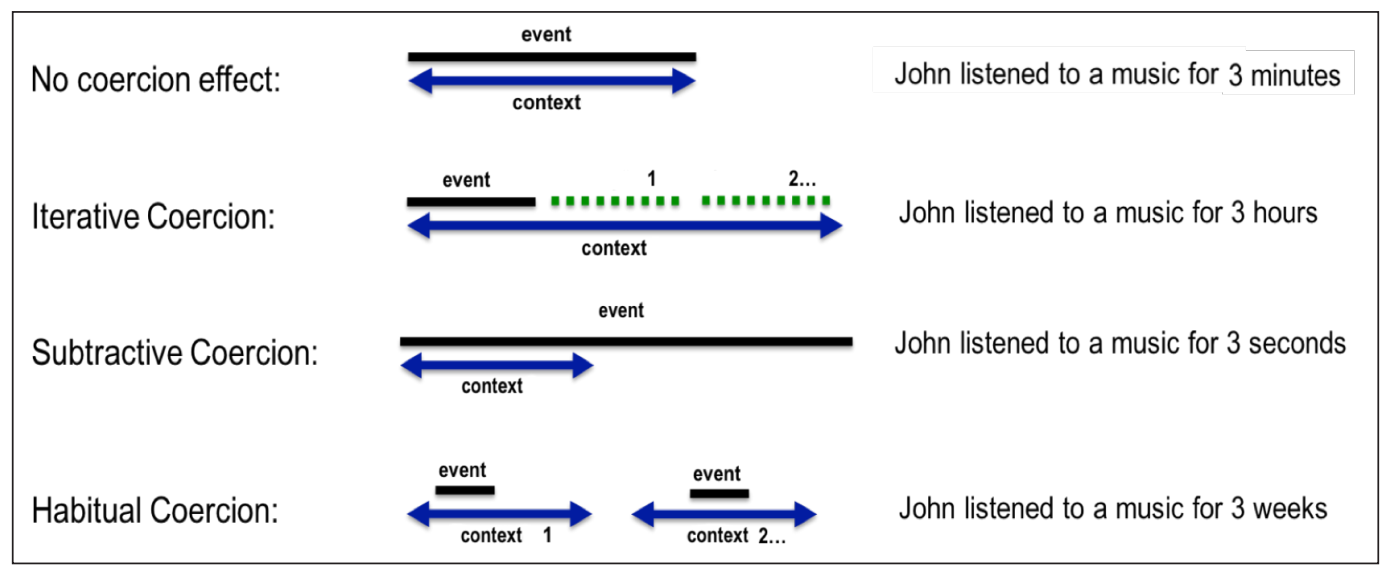

Figure 1. Representation of coercion effects following the time-perception-driven hypothesis

\footnotetext{
1 In our view, effects in Todorova et al. (2000a,b) are not caused by aspectual coercion, but by distributional properties of the complements. Aspectual coercion is possible in non-resultative punctual verbs (semelfactives) such as 'sneeze all day long' or 'blink for two minutes'. Todorova's stimuli are resultative punctuals (achievements) such as 'send a large check for many years'. If someone already sent a large check to his daughter, it is obvious that the same check cannot be sent twice.

2 Roughly, Event Classification is a typology of linguistic event types in Philosophy of Language. Aristotle proposed the first event classification in the 9th book of Metaphysics. The most influential event classification in Linguistics is Vendler's (1957). See Rosen (1999) or Sampaio \& França (2010) for a review. Dölling (2014) proposes his own classification.

3 Agentive, iterative, ingressive, inchoative, additive, subtractive, completive, stretching and habitual coercion.

4 Coll-Florit \& Gennari (2011) and Faber \& Gennari (2015) also propose that time perception can be observed in language processing. But these authors, differently from us, do not discuss aspectual coercion in their works, but focus on very different facets of language processing such tense and the influence of discourse contexts on sentence processing.
}

(3) a. During some hours, the girl fulfilled the form (iterative coercion)

b. During some seconds, the girl presented the project (subtractive coercion)

c. During some days, the girl eat cereal in the breakfast (habitual coercion)

Both event-classification-driven and time perceptiondriven hypothesis are compatible with experimental results reported to date and expand the scope of their predictions, hypothesizing with other types of aspectual coercion. 
Table 1. Three approaches on aspectual coercion

Iterative Coercion Hypothesis (PUSTEJOVSKY, 1995, JACKENDOFF, 1997)

Punctualty and Durativity are two settings of one parameter of Aspect.

These settings are present both in the verb and in temporal modifiers and one should match the other.

Punctual verbs, when used with durative modifiers, become iterative.

Predictions:

- Iterative shift of punctual events $\quad$ eg. Mary jumped all the day long

eg. John sneezed for two minutes

Event Classification Hypothesis (DÖLLING, 2014)

Aspectual Coercion is not reduced to iterative coercion.

There are several other kinds of changes in event meaning that requires a new event classification.

Each change in this classification is a kind of aspectual coercion.

\section{Predictions:}

- Pragmatic coercion when verbs are used in different event classes

\author{
a. Iterative Coercion \\ b. Habitual Coercion \\ from an episode to a habitual state: \\ eg. Play a song for one year \\ c. Subtractive Coercion \\ eg. The musician played the sonata for 2 minutes \\ d. Inchoative coercion \\ from an episode to a boundary: \\ eg. "Run at 7 "clock" \\ e. Stretching coercion from a moment to an episode: \\ eg. Slept for an hour
}

Time Perception Hypothesis (SAMPAIO, 2015; 2016)

Events have their own average duration in the real world. A song usually lasts for three minutes.

Listening to a song for some seconds or for some hours will trigger subtractive and iterative coercion, regardless of aspectual features.

Duration changes also implies different event classification.

Predictions:

- Semantic coercion when the temporal context is not enough or extrapolates the verb subjective duration.
Multiple events meaning eg. Have dinner for 3 hours Subtractive/incomplete meaning

eg. Give a conference for some seconds

Habitual meaning

eg. During his entire career, Nilton Santos played for Botafogo.
The present paper aims at testing the Time Perception-Driven hypothesis fully explained in Sampaio (2015). The next section 3 presents a self-paced reading experiment on subtractive, iterative and habitual coercion. Since Subtractive Coercion and Habitual Coercion have also been proposed by Dölling (2014), the test will present important evidences for the predictions of both hypotheses.

\section{Experiment 1: Coercion of durative events}

In order to test the Time-Perception-Driven hypothesis, we ran a self-paced reading experiment in Brazilian Portuguese to verify its major bet that different temporal contexts would indeed influence the reading times of durative events.

Participants. 32 native speakers of Brazilian Portuguese (18-25 y.o), all right handed with normal or corrected-to-normal vision participated in the experiment.
All participants were volunteers, students of UFRJ and the experiment followed the Declaration of Helsinki (2008) of ethical principles for research involving human participants.

Pretest. Prior to the main experiment, we normed 285 verbs by their subjective duration in a simple categorization test. A verb was presented at the center of a screen and ten participants ( 5 females) were to judge their duration between punctual, seconds, minutes and hours, presented at the top of the screen ${ }^{5}$. Their responses were given by pressing the numbers from

\footnotetext{
5 The pretest was applied to another 10 participants ( 5 females) presenting the temporal words in a decreasing magnitude order [hour, minutes, seconds, punctual]. However, while some verbs presented the same response behavior, other had their category inverted between the groups. A plausible explanation for that is an experimental bias in this experiment, a kind of STARC Effect (Spacial-Temporal Association of Response Codes), analogous to SNARC Effect (Spacial-Numerical Association of Response Codes; DEHAENE et al. 1993) in the categorization of verb duration. Since a deeper analysis is required to clearly understand the data, we eliminated the responses of the second group from our pretest (see Sampaio 2015 for more details).
} 
1 (punctual) to 4 (hours) or spacebar (to avoid the verb). All responses with the spacebar and RTs bellow 200ms and above $10 \mathrm{~s}$ were removed from the categorization analysis, eliminating about $0.03 \%$ of data. Only the verbs presenting the minimum of $50 \%$ of responses for minutes $(\approx 70 \%)$ were selected for the main test.

Materials. Sixteen transitive sentences were constructed using these verbs (Appendix 1). Since the sentences are the same between conditions, except by the word for duration (seconds, minutes, hours and days), we did not controlled verbs for lexical or semantic variables. All sentences were inserted in one of four durative contexts: some seconds (subtractive condition), some minutes (control condition), some hours (iterative condition) and some days (habitual condition). Our stimuli are exemplified in (4) below, totalizing four versions of each sentence distributed in Latin square design. We constructed 78 filler sentences with similar structure, including 16 sentences of another experiment.

(4) Duration Variable [ $\Delta \mathbf{t}]$ : seconds, minutes, hours or days

Durante $\mid$ alguns $[\Delta \mathrm{t}] \mid$ Beto $\mid$ cantou $\mid$ a música $\mid$ no palco do teatro

During $\mid$ some $[\Delta \mathrm{t}] \mid$ Beto $\mid$ sang $\mid$ a song $\mid$ at the stage of the theater

Task: Beto cantou a música? (Did Beto sing a song?) | Yes $[\mathrm{H}] /$ No $[\mathrm{J}]$

Procedure. Sentences were presented in an external 17 " IPS $60 \mathrm{~Hz}$ monitor placed about $60 \mathrm{~cm}$ from the subjects. Our stimuli used a white 28-point Arial font on a black background. The experiment is coded in Mathworks Matlab 7.14 2012a for Mac (OSX 10.9, Mavericks) using Psychtoolbox v3 (BRAINARD, 1997; KLEINER et al. 2007). Ten practice sentences were presented prior to the main test. All 32 participants presented accuracy rates above $80 \%$ at the practice trials. Each trial started with a fixation dot, presented for one second on the center of the screen. Participants were instructed to read the sentences at their own pace, pressing the spacebar to advance through the sentence. At the end of each trial, an interpretation question was presented in red font. Each participant took about 20 minutes to finish the experiment.

Results. Three participants did not reach $80 \%$ of accuracy in the main experiment and were eliminated from the analysis. For the 29 remaining participants, we trimmed data following the outlier labeling rule (TURKEY, 1977) using $g=2,2$ (HOAGLIN; IGLEWITZ; TURKEY, 1986). The procedure eliminated about $6 \%$ of the data. The reading times for each segment are represented in the Figure 2.

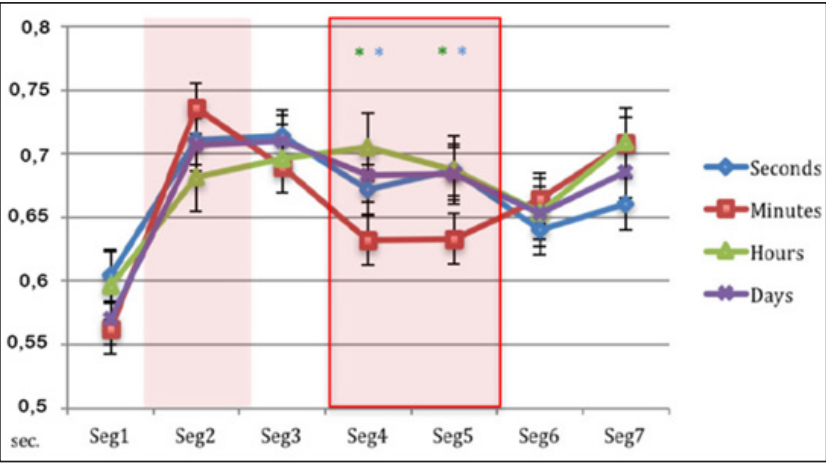

Durante | alguns $[\Delta \mathrm{t}]$ | Beto | cantou | a música | no palco | do teatro During | some $[\Delta \mathrm{t}] \quad$ Beto | sang | a song | at the stage | of the theater

Figure 2. Reading times for each segment of the sentence. The segments in red are our region of interest. Areas marked with a red line refer to significant effects.

The remaining reading times were not normally distributed according to Shapiro-Wilk test for normality (W<960, $p<.01$ ) leading us to use Wilcoxon SignedRank test of hypothesis for each of our unrelated paired samples.

Three regions of interest were defined. First, the segment 2 contains the word describing the magnitude of event duration. This region presents no significant effect. The second region is the verb, in the segment 4 . This area presents a significant increase of reading times from [minutes] to [seconds] $(Z=-2.183, p=.03)$ and to [hours] $(Z=-2.376, p=.018)$, however, no significant effect has been found for [days] $(Z=-1.752, p=.08)$. The same can be observed at the third area, the segment 5 containing the direct object. This region presents a significant increase in the reading times from [minutes] to [seconds] $(Z=-2.420$, $p=.016)$ and a marginal effect between [minutes] and [hours] $(Z=-1.933, p=.053)$. Any effect has been found from [minutes] to [days] $(Z=-1.790, p=.073)$. Reaction times to the interpretation question present no significant effect.

Table 2. Wilcoxon Signed-Rank Test results for each controlexperimental unrelated paired sample (Experiment 1)

\begin{tabular}{lccc}
\hline & Minutes-Seconds & Minutes-Hours & Minutes-Days \\
Segment 2 & $Z=-.145, p=.885$ & $Z=-.930, p=.353$ & $Z=-1.608, p=.108$ \\
Segment 4 & $Z=-2.183, p=.03$ & $Z=-2.376, p=.018$ & $Z=-1.752, p=.08$ \\
Segment 5 & $Z=-2.420, p=.016$ & $Z=-1.933, p=.053$ & $Z=-1.790, p=.073$ \\
RT & $Z=1.776, p=.076$ & $Z=-1.048, p=.295$ & $Z=-1.326, p=.185$ \\
\hline
\end{tabular}

Discussion. Results of the Experiment 1 were consistent with our initial hypothesis. Duration incongruences between events and their temporal contexts are observed online by a significant increase in the reading times at the region of the verb and of the direct object. 
However, only subtractive [some seconds] and iterative [some hours] coercion have been found.

Our analysis does not suggest a habitual coercion effect and fails to reject the null hypothesis. Nevertheless, it is important to notice that the visual analysis presents a similar increase in the average reading times at the critical segments for the habitual coercion condition as the ones observed for iterative and subtractive coercion.

By now, we can consider at least three hypotheses: (1) habitual coercion does not exist; (2) habitual coercion exists and cannot be observed by our methods and; (3) habitual coercion exists and our analysis fails to observe a significant effect. New experiments are necessary in order to evidence the existence or the absence of this effect.

\section{Discussion on Sampaio et al. (2014)}

By now, another way to shed light on the results for habitual coercion is to compare them with the first experiment on the time-perception-driven hypothesis, presented in Sampaio, França and Maia (2014). In this paper we presented a similar experiment in which we reported inconsistent effects between different habitual conditions [days, months and years]. The results present significant effects only between [minutes] and [years], in the word describing duration [eg. minutes/years] and in the task. Significant effects were also found at the end of the sentence, that can be related to wrap up effects (Figure 3).

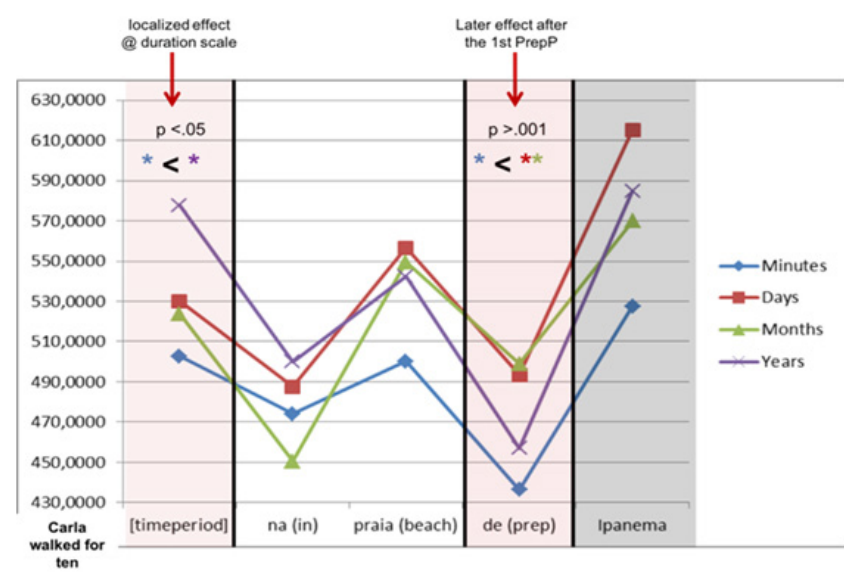

Figure 3. Reading times of Sampaio, França \& Maia (2014, p. 150).

However, there were some methodological and statistical problems with this test and with its first analysis. First, in the stimuli, our sentences used quantified temporal contexts that keep the same number between conditions. For instance, sentences such as "walk for 10 minutes" were compared to others such as "walk for 10 years", that is too long a time, inducing a huge temporal difference between conditions. This problem was solved in the new experiment presented in the last section by using "some $[\Delta \mathrm{t}]$ ". As for the statistical problems, the data were trimmed using 6 standard deviations which is basically a visual inspection. Also, there was no test for normality distribution either, that would have indicated the suitability of applying an ANoVA test of hypothesis.

In section 4, we present the new standardized analysis of this experiment which will make it comparable to the present experimental venture described in this paper.

\subsection{A reanalysis of Sampaio et al. 2014: Habitual Coercion of durative events}

We re-analyze the data presented in Sampaio, França and Maia (2014) in which we had reported different and inconsistent effects between the three unrelated paired samples (minutes-days, minutes-months, minutesyears). Since data analysis of both tests followed different methods, the first step to understand the real differences between them was to unify the methods of data analysis.

Participants. 36 native speakers of Brazilian Portuguese, 19 females (18-25 y.o), right handed with normal or corrected-to-normal vision participated in the experiment. All participants were volunteers, students of UFRJ, and the experiment follows the Declaration of Helsinki (2008) of ethical principles for research involving human participants.

Materials. The materials consist of twelve durative sentences (Appendix 2) distributed in four habitual contexts [minutes, days, months and years]. Since the sentences were identical between conditions, except by the word describing the temporal context, we did not control the verbs by lexical or semantic variables. Each sentence was followed by an interpretation question in blue font, as exemplified in (5) below. The experimental sentences were distributed in a Latin Square Design and represent $1 / 3$ of the total number of stimuli.

(5) Carla $\mid$ caminhou $\mid$ por $|\operatorname{dez}|[\Delta \mathbf{t}] \mid$ na $\mid$ praia $\mid$ de $\mid$ Ipanema.

Carla walked for ten $[\Delta \mathbf{t}]$ on Ipanema Beach.

$\Delta t$ : (a) minutes, (b) days, (c) months, (d) years.

Question: Carla caminhou na praia de Ipanema? (Did Carla walk on Ipanema beach?)

Procedures. The word-by-word self-paced reading test was coded and applied using Psyscope B57 (COHEN et al. 1993) on a MacBook White 15" with a $60 \mathrm{~Hz}$ screen and running OSX 10.5.8 (Leopard). Stimuli were 
presented in Times New Roman 24 white font in a black background. Questions were presented in a blue font. Ten practice trials were presented to the participants prior to the test. Sentences were randomized by the software and were preceded by a fixation cross presented for one second. Then a series of 5 hashtags (\#) indicate that the keyboard is ready. Participants use the [spacebar] to advance through the sentence. The interpretation questions were answered yes [k] in green, or no [1] in red. Three volunteers did not reach $80 \%$ of accuracy at the interpretation questions and were replaced by another three participants. The mean accuracy for the total of 36 participants was $94 \%$. Each participant took about 15 minutes to finish the test.

Results. For this paper, the original raw data were reanalyzed using the same methods described in the first experiment. Data were trimmed by the outlier labeling rule (TURKEY, 1977) using $g=2.2$ (HOAGLIN; IGLEWITZ; TURKEY, 1986). The procedure eliminated about $6 \%$ of the data. Figure 4 presents the average reading times for each word of the sentence.

The remaining data were not normally distributed (Shapiro-Wilk ; $\mathrm{W}<932, p<.006$ ) which led us to apply the Wilcoxon Signed-Rank test for each of our unrelated non-parametric paired samples. A visual analysis suggests a slight difference in the reading times at the segments 5 and 7. However, no relevant differences were found at the segment 5, 7 or at the RTs (Table 3).

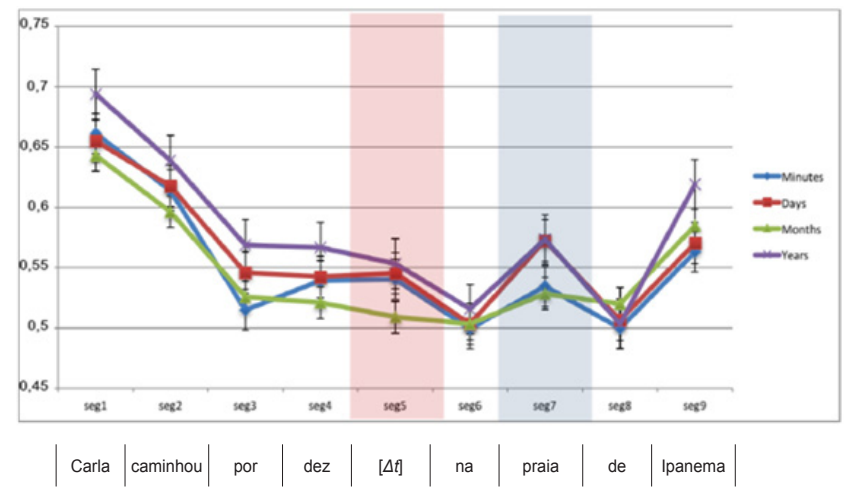

Figure 4. Reading times for each segment of the sentence (in milliseconds). The segment in red is the region of interest. The segment in blue is selected by a visual analysis and tested for statistical significance.

Table 3. Wilcoxon Signed-Rank Test results for each controlexperimental unrelated paired sample (Experiment 2)

\begin{tabular}{lccc}
\hline & Minutes-Days & Minutes-Months & Minutes-Years \\
Segment 5 & $Z=-.291, p=.771$ & $Z=-.981, p=.327$ & $Z=-.394, p=.794$ \\
Segment 7 & $Z=-.874, p=.382$ & $Z=-.229, p=.819$ & $Z=-.776, p=.438$ \\
RT & $Z=-.135, p=.892$ & $Z=-.141, p=.888$ & $Z=-1734, p=.083$ \\
\hline
\end{tabular}

Discussion. This reanalysis fixed several experimental problems we had with our 2014 test. Once again it did not point to any significant effect of habitual coercion and thus habitual coercion hypothesis failed to reject the null hypothesis.

There were also some contrasts between the test we had applied earlier and the one presented in section 3. In the earlier test to which we now presented a reanalysis we had not controlled the duration of the events in a pretest. Also, instead of using a general quantifier (some) before the different cycles (days, months, etc) we used a specific number. So, we compared sentences such as "During 10 minutes Carla walked in Ipanema Beach", that is quite plausible, with another condition in which "Carla walked for 10 years in Ipanema Beach", that is a quite long period. We thought that this use of a specific number might have biased the test. However, even with the use of the general quantifier (some) to all sentences, we did not find any difference.

\section{General Discussion:}

As we can observe, both hypotheses - the Time Perception-Driven and the Event-Classification-Driven - predict the habitual coercion but could not find it. However, we could find differences between, on one hand, days and, on the other, seconds, minutes and hours.

To sum up our results, we found that temporal words such as [seconds], [minutes] and [hours] refer to durations and tend to be applied to a single event. On the other hand, [days], [months] and [years] are not durations. They are cyclical time periods in which the event can happen once a day or even be randomly distributed during some days.

Using just linguistic theory, it is possible to say that durations are different than habits and, thus, require different cognitive processes, opening the question of why they are cognitively distinct. In a similar way, it is possible to argue that our hypothesis that links timeperception studies with event duration semantics makes it compatible with its sensitivity to the two different natures of time perception - the durations and the cycles (FRAISSE, 1984; BUHUSI; MECK, 2005, p. 756). It also makes it, perhaps, closer to a full fledge explanation of the phenomenon. Even if sentence processing is different in nature than time-perception processing, it is plausible that time-perception is related to the acquisition of the mean duration of events, as explained in detail in Sampaio, França \& Maia (2014, p. 146) and Sampaio (2015).

Nevertheless, more experiments are required for us to fully comprehend the reality and the mechanisms of habitual coercion. At this point, our question and further pursuits is what different interdisciplinary methods can be used to directly evidence the habitual coercion effect. 


\section{Acknowledgements}

We are grateful to Julie Franck, Matthew Mattel, Marcus Maia, Giovanna Rizzo Fonseca and Virginie van Wassenhove for their comments. This work was supported by CAPES Foundation, Ministry of Education of Brazil (BEX 10.65-12-0), The Sao Paulo Research Foundation (2016/13920-9), the National Council for Scientific and Technological Development (CNPq, GD 141.963/2011-5 and PQ 312.079/2016-8) and FAPERJ (203.055/2017).

\section{References}

ALFORD, Danny Keith Hawkmoon. Reality, Time and Language as field wave and particle, Special Field Examination, Berkeley, 1981.

BŁASZCZAK, Joanna; KLIMEK-JANKOWSKA, Dorota. Aspectual coercion versus blocking: experimental evidence from ERP study on Polish converbs. In: BŁASZCZAK, Joanna (ed). How categorical are categories? New approaches to the old questions of Tense, Aspect and Mood. Chicago: The University of Chicago Press, 2016.

BRENNAN, Jonathan; PYLKKÄNEN, Liina. Processing Events: Behavioral and Neuromagnetic Correlates of Aspectual Coercion. Brain and Language, n. 106, p. 132-143, 2008.

BYLUND, Emanuel; ATHANASOPOULOS, Panos. The Whorfian time warp: representing duration through the language hourglass. Journal of Experimental Psychology: General, 2017.

CHAN, Ho Leung. Aspectual Coercion in non-native speakers of English. In: KNAUFF, Markus; PAUEN, Michael; SEBANZ, Nathalie; WACHSMUTH Ipke. (Eds.). Proceedings of the 35th Annual Conference of the Cognitive Science Society, Austin, TX: Cognitive Science Society, p. 2006-2011, 2013.

COLL-FLORIT, Marta; GENNARI, Silvia. Time in language: Event duration in language comprehension. Cognitive Psychology, v. 62, n. 1, p. 41-79, 2011.

DE SWART, Henriette, Aspect shift and coercion. Natural Language \& linguistic Theory, n. 16, p. 347-385, 1998.

DÖLLING, Johannes. Aspectual Coercion and Eventuality Structure. In: ROBERKING Klaus (Ed.). Events, Arguments and Aspects: Topics in the Semantics of Verbs (Studies in Language Companion Series 152), Amsterdam: John Benjamins Publishing Company, 2014. p. 189-226.

FABER, Mirthe; GENNARI, Silvia P. Representing time in language and memory: The role of similarity structure, Acta Psychologica, v. 156, p. 156-261, 2015.

FRAISSE, Paul. Perception and Estimation of Time, Annual Review of Psychology, n. 35, p. 1-36, 1984.

GAUTHIER, Baptiste; VAN WASSENHOVE, Virginie (2016). Cognitive mapping in mental time travel and mental space navigation. Cognition, v. 154, p. 55-68.

GAUTHIER, Baptiste; VAN WASSENHOVE, Virginie. Time is not space: core computations and domain-specific networks for mental travels. Journal of Neuroscience, v. 36, n. 47, p. 11891-11903, 2017.
HOAGLIN, D. C.; IGLEWICZ, B.; TURKEY, J. W. Performance of some resistant rules for outlier labeling, Journal of American Statistical Association, n. 81, p. 991-999, 1986.

HORNSTEIN, Nobert. Tense and Universal Grammar, MIT Press, 256p. 1993.

JACKENDOFF, Ray. The architecture of the language faculty. Cambridge, MA: MIT Press, 1997.

MANI, Inderjeeet; PUSTEJOVSKY, James; GAIZAUSKAS, Robert. The Language of Time: A Reader, Oxford University Press, 2005. 600 p.

MOENS, Marc. Tense, Aspect and Temporal Reference, 1987. 211f. Tese (Doutorado) - University of Edinburgh, Edinburg, 1987.

PACZYNSKI, Martin; JACKENDOFF, Ray; KUPERBERG, Gina. When events change their nature: The neurocognitive mechanisms underlying aspectual coercion. Journal of Cognitive Neuroscience, v. 26, n. 9, p. 1905-1917, 2014.

PICKERING, Martin; MCELREE, Brian; FRISSON, Steven; CHEN, Lilian; TRAXCLER, Matthew. Aspectual Coercion and underspecification. Discourse Processes, v. 42, p. 131-155. 2006

PUSTEJOVSKY, James. The generative lexicon. Cambridge: MIT Press, 1995

REICHENBACH, Hans. (1947). Elements of Symbolic Logic. Reimpresso por Dover Publications, 1980.

ROSEN, Sara Thomas. The syntactic representation of linguistic events, GLOT International, v. 4, n. 2, p. 3-11, 1999.

SAFFRAN, Jenny; JOHSON, Elizabeth; ASLIN, Richard; NEWPORT, Elissa. Statistical Learning of Tone Sequences by Human Infants and Adults, Cognition, v. 70, p. 27-52, 1999.

SAMPAIO, Thiago. Coerção Aspectual: Uma abordagem linguística da Percepção do Tempo. 2015. 398f. Tese (Doutorado em Linguística) - Universidade Federal do Rio de Janeiro, Rio de Janeiro, 2015.

SAMPAIO, Thiago. Percepção do Tempo: da Psicologia para a Psicolinguística, Letras de Hoje, v. 51, n. 3, 2016.

SAMPAIO, Thiago; FRANÇA, Aniela; MAIA, Marcus. Does Time Perception Influence Language Processing? Self-Paced Reading Evidence of Aspectual Coercion in Durative Events. In: CHRUSZCZEWSKI, Piotr (Org.). Languages in Contact: Ways to Protolanguage 3. Wroclaw: Wyższa Szkoła Filologiczna we Wrocławiu \& Polska Akademia Nauk, 2014. p. 139-156.

SMITH, Carlota. The Parameter of Aspect. Dordrecht: Kluwer Academic Publishers, 1991.

TENNY, Carol Lee. The Aspectual Interface Hypothesis. In: SAG, Ivan; SZABOLCSI, Anna (Eds.). Lexical Matters, Stanford: Center for the Study of Language and Information, 1992. p. 1-28.

TODOROVA, Marina; STRAUB, Kathy; BADECKER, William; FRANK, Robert. Aspectual coercion and the online computation of sentential aspect. Proceedings of the 22nd Annual Conference of the Cognitive Science Society, 2000a. p. 3-8.

TODOROVA, Marina; STRAUB, Kathy; BADECKER, William; FRANK, Robert. Processing correlates of aspectual coercion. Comunicação apresentada no Workshop on Events and Paths, ESSLLI XII, Birmingham, England, 2000b. 
TOWNSEND, David. Aspectual Coercion in Eye Movements. Journal of Psycholinguistic Research, v. 42, n. 3, p. 281-306, 2012.

TREISMAN, Michael. Temporal discrimination and the indifference interval: Implications for a model of the 'internal clock'. Psychological Monographs, v. 77, n. 13, 1-31, 1963.
TURKEY, J.W. Exploratory Data Analysis, Reading, MA: Addison-Wesley, 1977.

VENDLER, Zeno. Linguistics in Philosophy, Ithaca: Cornell University Press. 1967.

YANO, Masataka. Temporal Dynamics of Syntactic and Semantic Prediction. 2016. 176f. Tese (Doutorado em Linguística) - Kyushu University, Kyushu, Japão, 2016.

\section{APPENDIX 1 \\ List of verbs used in the pretest}

abalar, abrir, acariciar, adicionar, adoçar, adoecer, afogar, afugentar, alcançar, alegrar, almoçar, animar, anotar, anunciar, apagar, apertar, apreciar, aprender, apresentar, agarrar, arranhar, arriscar, assar, assassinar, assinar, assistir, assustar, atender, aterrorizar, atirar, atropelar, avaliar, avisar, avistar, bailar, barbear, bater, beber, berrar, bisbilhotar, brigar, buscar, calar, caminhar, cantar, casar, catar, chatear, chegar, chover, chutar, clicar, cobrar, cochilar, colocar, colorir, comemorar, comer, comparar, comprar, confessar, confiar, consertar, contar, conversar, copiar, correr, corrigir, cortar, cozinhar, cruzar, cuidar, dançar, dar, dedetizar, dedurar, defender, degustar, deixar, depositar, descansar, descer, descobrir, desenhar, desligar, deslizar, desvendar, digitalizar, digitar, dirigir, discutir, divertir, dormir, educar, eliminar, elogiar, embarcar, empacotar, encalhar, encaminhar, encontrar, encostar, endireitar, enganar, engasgar, engatilhar, engavetar, engolir, empobrecer, enriquecer, ensinar, entregar, entrevistar, entristecer, entupir, envelhecer, enviar, enxergar, enxugar, errar, esbarrar, escanear, escolher, esconder, escrever, esfriar, esmagar, esperar, espirrar, esquentar, estilhaçar, estragar, estudar, explodir, fabricar, facilitar, falar, fazer, fechar, felicitar, festejar, fincar, fisgar, folhear, formatar, fotografar, fraturar, fritar, fugir, fumar, furar, ganhar, gesticular, golpear, governar, gravar, gritar, guardar, diminuir, dividir, multiplicar, habilitar, hostilizar, iluminar, imitar, importar, imprimir, incendiar, incomodar, informar, iniciar, insistir, instalar, investigar, irritar, jantar, jogar, judiar, juntar, justificar, lamber, ler, levantar, levar, ligar, limpar, lutar, marcar, matar, medicar, melhorar, mergulhar, misturar, molhar, montar, morrer, mudar, nadar, nascer, nevar, numerar, obedecer, observar, oferecer, olhar, operar, orar, organizar, pagar, parir, passear, pensar, pentear, perder, perturbar, pescar, pesquisar, picotar, pilotar, pinçar, pintar, pisar, piscar, planar, preencher, prender, preocupar, presentear, pressionar, processar, procurar, proteger, protestar, pular, qualificar, quebrar, queimar, rabiscar, rasgar, rebater, receber, registrar, relampejar, resgatar, responder, rezar, rir, riscar, saciar, sair, saltar, secar, segurar, sensibilizar, sentar, sobrevoar, socar, soluçar, sorrir, subir, sufocar, tagarelar, teclar, telefonar, temer, testar, tocar, tomar, torcer, trabalhar, trafegar, trair, transformar, trazer, treinar, tremer, triturar, triunfar, trocar, vender, ver, vestir, viajar, visualizar, voar 


\section{APPENDIX 2}

\section{Stimuli List and glossa - Experiment 1}

1. Durante $\mid$ alguns $[\Delta \mathrm{t}] \mid$ Joana $\mid$ comeu $\mid$ o cereal $\mid$ no café $\mid$ da manhã $G$-During $\mid$ some $[\Delta t] \mid$ Joana $\mid$ eat $\mid$ the cereal $\mid$ at the breakfast $\mid \mathrm{AM}$

2. Durante $\mid$ alguns $[\Delta \mathrm{t}] \mid$ Bruna $\mid$ degustou $\mid$ o buffet $\mid$ no bistrô $\mid$ do bairro $G$-During $\mid$ some $[\Delta t] \mid$ Bruna $\mid$ tasted $\mid$ the buffet | at the bistro | of the neighborhood

3. Durante $\mid$ alguns $[\Delta \mathrm{t}] \mid$ Marina $\mid$ limpou $\mid$ a mesa $\mid$ no quarto $\mid$ do filho $G$-During $\mid$ some $[\Delta t] \mid$ Marina $\mid$ cleaned $\mid$ the table $\mid$ at the room $\mid$ of her son

4. Durante alguns $[\Delta \mathrm{t}] \mid$ Raquel $\mid$ anotou $\mid$ a matéria $\mid$ no caderno $\mid$ do colega $G$-During $\mid$ some $[\Delta t] \mid$ Raquel $\mid$ took note (of) $\mid$ the discipline notes $\mid$ in the notebook $\mid$ of her colleague

5. Durante $\mid$ alguns $[\Delta \mathrm{t}] \mid$ Ana $\mid$ desenhou $\mid$ o boneco $\mid$ no caderno $\mid$ de rascunho $G$-During $\mid$ some $[\Delta t] \mid$ Ana $\mid$ drew $\mid$ a doll $\mid$ in the notebook | for drafts

6. Durante $\mid$ alguns $[\Delta \mathrm{t}]|\mathrm{Bia}|$ apresentou $\mid$ o projeto $\mid$ na aula $\mid$ de história $G-$ During $\mid$ some $[\Delta t]|\mathrm{Bia}|$ presented | the project $\mid$ in the class | of History

7. Durante $\mid$ alguns $[\Delta \mathrm{t}] \mid$ Helen $\mid$ discutiu $\mid$ o estudo $\mid$ no evento $\mid$ da faculdade $G$-During $\mid$ some $[\Delta t] \mid$ Helen $\mid$ discussed $\mid$ the study $\mid$ in the event $\mid$ of the Faculty

8. Durante alguns $[\Delta \mathrm{t}] \mid$ Luara $\mid$ preencheu $\mid$ a ficha $\mid$ na mesa $\mid$ do escritório $G$-During $\mid$ some $[\Delta t] \mid$ Luara $\mid$ fullfilled $\mid$ the form $\mid$ at the desk $\mid$ of the office

9. Durante $\mid$ alguns $[\Delta \mathrm{t}] \mid$ Beto $\mid$ cantou $\mid$ a música $\mid$ no palco $\mid$ do teatro $G$-During $\mid$ some $[\Delta t] \mid$ Beto $\mid$ sang $\mid$ a song $\mid$ at the stage $\mid$ of the theater

10. Durante $\mid$ alguns $[\Delta t] \mid$ Felipe $\mid$ instalou $\mid$ o linux $\mid$ no laptop $\mid$ da empresa $G$-During $\mid$ some $[\Delta t] \mid$ Felipe | installed | (the) linux | on the laptop | of the company

11. Durante $\mid$ alguns $[\Delta \mathrm{t}] \mid$ João $\mid$ perturbou $\mid$ o colega $\mid$ na sala $\mid$ do colégio (removed) $G$-During $\mid$ some $[\Delta t] \mid$ João $\mid$ disturbed $\mid$ the colleague $\mid$ at the room $\mid$ of the school

12. Durante $\mid$ alguns $[\Delta \mathrm{t}] \mid$ Ricardo $\mid$ rezou $\mid$ o credo $\mid$ na igreja $\mid$ da cidade $G$-During $\mid$ some $[\Delta t] \mid$ Ricardo | prayed $\mid$ The Apostles Creed $\mid$ at the church $\mid$ of the city

13. Durante $\mid$ alguns $[\Delta \mathrm{t}] \mid$ Leo $\mid$ empacotou $\mid$ a encomenda $\mid$ na agência $\mid$ dos correios $G$-During $\mid$ some $[\Delta t] \mid$ Leo $\mid$ packed $\mid$ the order $\mid$ at the office $\mid$ of the postal service

14. Durante $\mid$ alguns $[\Delta t] \mid$ Marco $\mid$ confessou $\mid$ o crime $\mid$ na delegacia $\mid$ de polícia $G$-During $\mid$ some $[\Delta t] \mid$ Marco $\mid$ confessed | the crime $\mid$ at the office $\mid$ of the police

15. Durante $\mid$ alguns $[\Delta \mathrm{t}] \mid$ Alan $\mid$ imprimiu $\mid$ o dossiê $\mid$ na xerox $\mid$ da faculdade $\mid$ $G$-During | some $[\Delta t] \mid$ Alan | printed | the files $\mid$ at the copy room $\mid$ of the university

16 Durante $\mid$ alguns $[\Delta t] \mid$ Henrique | fritou $\mid$ a carne $\mid$ no fogão $\mid$ da cozinha $G$-During $\mid$ some $[\Delta t] \mid$ Henrique $\mid$ fried $\mid$ the meat $\mid$ on the stove $\mid$ of the kitchen 


\section{APPENDIX 3 \\ Stimuli List and glossa - Experiment 2 (Reanalysis of Sampaio, França \& Maia, 2014)}

1. Carla caminhou por $10[\Delta t]$ na praia de Ipanema $G$-Carla walked for $10[\Delta t]$ in Ipanema Beach

2. Liliane nadou por doze $[\Delta t]$ na piscina do clube $G$-Liliane swum for twelve [At] in the club's pool

3. Raquel brincou por trinta $[\Delta t]$ no pátio da escola $G-$ Raquel played for thirty $[\Delta t]$ in the schoolyard

4. Matheus jogou por cinco $[\Delta t]$ no time de futebol $G$ - Matheus played for five [ $\Delta t]$ in the football team

5. Camila dormiu por quinze $[\Delta t]$ no quarto da colega $G$ - Camila slept for fifteen $[\Delta t]$ in her friend's room

6. Renato lutou por seis $[\Delta t]$ na academia de karatê $G$ - Renato fight for six [Ut] in Karate Academy

7. Joana viajou por vinte $[\Delta t]$ no carro do Marcelo $G$ - Joana traveled for twenty [At] in Marcelo's car

8. Eduarda correu por três $[\Delta t]$ na pista de corrida $G-E d u a r d a$ ran for three $[\Delta t]$ in the cinder track

9. Julia trabalhou por nove $[\Delta t]$ na loja de calçados $G-J u l i a$ worked for nine $[\Delta t]$ in shoe store

10. Lucas ajudou por dois $[\Delta t]$ nas tarefas do amigo $G$ - Lucas helped for two [Dt] in his friend's works

11. Isabelle dançou por oito $[\Delta t]$ no palco do teatro $G$-Isabelle danced for eight [ $\Delta t]$ in theater stage

12. Maria estudou por nove $[\Delta t]$ no curso de turismo $G-$ Maria studied for nine $[\Delta t]$ in the course of tourism 